Н. М. Шарманова

\title{
КОДИ КУЛЬТУРИ ТА ЇХ РЕПРЕЗЕНТАЦІЯ В УСТАЛЕНИХ СЛОВЕСНИХ КОМПЛЕКСАХ
}

Шарманова Н. М. Коди культури та їх репрезентація в усталених словесних комплексах.

У статті проаналізовано усталені словесні комплекси як мовні знаки, що вербалізують систему культурних кодів.

Ключові слова: код культури, система кодів культури, усталений словесний комплекс.

Шарманова Н. Н. Коды языка и их репрезентация в устойчивых словесных комплексах.

В статье проанализированы устойчивые словесные комплексы как языковые знаки, вербализирующие систему культурных кодов.

Ключевые слова: код культуры, система кодов культуры, устойчивый словесный комплекс.

Sharmanova N. M. Culture Codes and Their Representation in Stable Word Complexes.

The article analyzes stable word complexes as language symbols that verbalize the system of language codes.

Key words: culture codes, the system of language codes, stable word complexes. 
В основі світосприйняття кожного народу лежить своя система предметних значень, соціальних стереотипів, когнітивних схем, відбитих у культурних національних кодах, відтак свідомість завжди етнічно зумовлена. Виразними експонентами культурно позначеної інформації $\epsilon$ усталені словесні комплекси як регулярні комбінації словесних знаків, які є стереотипними автономними лінгвістичними утвореннями із заданими за традицією значенням і формою. Усталені словесні комплекси характеризуються перш за все лексикограматичною спаяністю в поєднанні з контекстуальною зумовленістю використання і здатністю автоматично відтворюватися в мові.

Актуалізація етнокультурного компонента в таких словесних комплексах певною фіксує національно значущу інформацію, відтворює культурну пам'ять носіїв мови. Порівняємо: у близькоспоріднених мовах, зокрема рос. Ищи, догоняй ветра в поле та укр. Шукай, доганяй вітра (вітру) в полі; лови вітра в полі (1, с. 88); рос. утром и вечером укр. рано й вечір (уранці ц̌ увечері), встаючи й лягаючи (1, с. 89). Відповідно спостерігаємо і в неспоріднених мовах, наприклад: англ. Apse upon thee! (формула із семантикою незадоволення); рос. Быть на осине (кому-либо) як побажання загибелі, у яких компонент осика (осина, apse) пов'язаний із народними повір'ями, за якими нібито Іуда повісився на цій деревині після зради Христа. Лексема осика розкриває інтертекстуальний зміст концептів біблійної символіки, відтак маємо його фіксацію не лише у світовій та - виразно - у слов'янській міфології, а й у регулярно відтворюваних сполуках укр. Тремтить (труситься) як (мов, наче ...) осичина (як осиковий лист, мов стрепетів лист, як лист на трепеті); труситься як на ножі рос. Дрожит (трясется) как осиновый лист (1, с. 610).

Мова зберігає й передає 3 покоління в покоління лише ті усталені сполуки, які прямо або опосередковано співвідносяться 3 еталонами, стереотипами й унікаліями національної культури - як матеріальної, так i духовної. Виступаючи в ролі експонентів культурних знаків, вони не лише зберігають пам'ять про мотивацію значення, а й закріплюють відтворене в їх культурних конотаціях світорозуміння носія мови, а відтак є репрезентантами базових кодів культури, засвоюючи які, комунікант усвідомлює власну причетність до етносу, стає носієм певного психо- й етнотипу.

У сучасному вітчизняному й зарубіжному мовознавстві актуальними є студії, присвячені осмисленню поняття кодування мови й опису того чи того лінгвокультурного коду. Система культурних кодів є підгрунтям надгрупової спільноти, використовує різні символи (c) Н. М. Шарманова, 2013. 
для самоідентифікації (Т. Б. Щепанська). Суттєві для культури смисли, на думку С. М. Толстої, можуть виражатися засобами різноманітних кодів, кожний із яких репрезентує свою структуралізацію та концептуалізацію певного конкретного смислу [7, с. 333].

Мета статті полягає в описі усталених словесних комплексів як репрезентантів кодів української культури. Мета розвідки передбачає реалізацію таких завдань: 1) розкрити мовний вимір лінгвокультурних кодів в усталених сполуках; 2) з'ясувати символьні функції репрезентантів соматичного, просторового, часового, предметного, біоморфного кодів; 3) установити стереотипізованість антропоморфного й аксіологічність духовного кодів культури.

Код вважають одним із центральних понять лінгвокультурологічної наукової парадигми й базовим семіотичним терміном. Він утілює відповідність між планом змісту і планом вираження знака, задає «значущість знака, а інтерпретатор цю значущість розкриває, «розшифровує», тобто розуміє знак» [2, с. 30]. Кодом називають систему образів, яка належить до певної культурної сфери або ж артефакти культури, що виступають у знаковій функції (Ю. М. Лотман).

Культура, за В. М. Телія, з'являється тоді, коли біологічні фактори опанування світу набувають соціального (морального) і духовного змісту у формах архетипних моделей світу [6]. Коди культури співвідносяться 3 давніми архетипними уявленнями людини, тож i сприймаються як феномени, універсальні за своєю природою та властиві лише людині. У процесі кодування фіксуються примітивні уявлення про Всесвіт, але їх вияв, міра значущості у певній окремій культурі, а також образи, у яких вони реалізуються, завжди національно детерміновані.

Культурний код - це система знаків матеріального й духовного світу, що стали носіями культурних смислів; «у процесі освоєння людиною світу вони втілили в собі культурні смисли, які «прочитуються» в цих знаках» [2, с. 30-31]. Культурний код транслює основні світоглядні оріснтири того чи того народу. Тому В. В.Красних подає дещо інше тлумачення терміна. Під кодом культури вона розуміє сітку, яку культура накидає на навколишній світ, репрезентуючи його членування, категоризацію, структурування в мовній свідомості, у мові та дискурсі [3, с. 232].

У «Словнику термінів міжкультурної комунікації» осмислюються різні підходи до розуміння сутності коду культури. У цій праці подане досить розлоге тлумачення основного поняття: «1. Спосіб, яким конкретна культура членує, категоризує, структурує, оцінює світ, що оточує членів певної національної лінгвокультурної спільноти <..> 
2. Сукупність знаків (символів), смислів та їхніх комбінацій, котрі наявні у будь-якому предметі культури певної національної лінгвокультурної спільноти» [1, с. 74].

Вітчизняні й зарубіжні мовознавці А. Баранов, Ф. С. Бацевич [1], Д. О. Добровольський, В. В. Красних [3], Р. Макін, О. С. Пальчевська, Ч. Ріллмор, Л. В. Савченко [4], О. О. Селіванова, В. М. Телія [6] та ін. визначають систему культурних кодів й зараховують до базових такі коди культури: соматичний, просторовий, часовий, предметний, біоморфний, антропоморфний, духовний.

Білоруська дослідниця А. А. Станкевіч виділяє, крім зазначених, i рослинний код культури [5, с. 148-150]. Л. В. Савченко, розкриваючи систему етнокодів духовної культури та їх представлення у фразеології української мови, до наведених вище додає (або переосмислює наявні) міфологічний, етіологічний, демонологічно-антропоморфний, релігійний, антропний, фітоморфний культурні коди, розкриваючи їх ментальний, акціональний i вербально-акціональний зрізи. Виокремлено також одиниці на позначення субстанціональної групи лінгвокультурних кодів [4, с. 147-515].

Пропонуємо розглянути базові коди культури, виділення яких не викликає жодних сумнівів переважною більшістю лінгвістів. Можливим видається акцентувати на соматичному, просторовому, часовому, предметному, біоморфному, антропологічному й духовному кодах, репрезентованих в усталених словесних комплексах. Вони розкривають еталонне й стереотипне в досвіді народу, пов'язаного 3 його культурними традиціями, і тим самим роблять загальнозрозумілим для носіїв мови (М. Ф. Алефіренко, В. М. Мокієнко, Є. М. Солодухо та ін.).

Соматичний код вважається найдавнішим, оскільки людина почала осягати навколишній світ 3 пізнання самої себе. Звідси ж розпочалось окультурювання людиною навколишнього світу.

Соматичним кодом культури є спосіб пізнання або уявлення людини про реальний світ через органи чуття, тіло, що «кодуються» в пам'яті людини. У ньому особливе місце посідають символьні функції різних частин тіла. Роль символу людини (як такої або через іi характеристику) можуть виконувати частини людського тіла, зокрема: голова: голова замакітрилася (СФУМ, с. 182); рахувати по головах (СФУМ, с. 149); язик: довгий язик (ФСУМ, с. 975); зав'язати язик (ФСУМ, с. 975); око: недремне око (ФСУМ, с. 584); не привчене око маєи (ФСУМ, с. 589); ніс: з-під (з-перед) [самого] носа (1, с. 558); чути, почути носом щзо (1, с. 559); рука: важка рука (ФСУМ, с. 764); рука в руку (ФСУМ, с. 764); нога: нога за ногою (ФСУМ, с. 553); з 
ноги на ногу (ФСУМ, с. 554). Отже, через усвідомлення себе, власної будови як частини цілої світобудови людина прийшла до аналізу Всесвіту, екстраполюючи свої знання про себе на навколишню дійсність. Шляхом осмислення реальності людина знов і знов повертається до опису самої себе, накладаючи на себе знання про світ.

Мовний вимір простору представлено просторовим кодом культури, яким номінують світоглядні уявлення людини через антропоморфні метафори. Він $є$ одним із універсальних культурних кодів, що має два вияви просторової орієнтації, наприклад: Іти (хилитися, гнутися), куди вітер віє (дме) (1, с. 88); за вітром (1, с. 88). Це випливає із закону асиметричного дуалізму мовних знаків, що входять до складу стійких словосполучень. 3 одного боку, просторові лексеми в інтегрованому змісті фразеологізмів позбавляються буквальної семантики й перетворюються на позначення інших культурних кодів, зокрема духовного, аксіологічного тощо. 3 іншого, до просторового коду зараховуються знаки інших концептосфер і кодів, зокрема соматичного, біоморфного, предметного й часового. Просторовий код на підставі знакових перенесень i змістових перетворень поєднується 3 іншими кодами людської культури, насамперед через «привласнення» суб'єктом простору. Просторовий код поєднаний із розчленовуванням простору: білий світ (СФУМ, c. 636); той світ (СФУМ, с. 636) тощо.

Власне просторовий код важко розвести 3 соматичним кодом культури в тій частині, яка стосується будови світу, оскільки більшість антропоморфних метафор у просторовому коді засвідчує певне розчленовування простору. Соматичний код накладається на просторовий i зумовлює просторові уявлення людини, структурування дійсності: рукою махнути (ФСУМ, с. 773); раз ступнути (ФСУМ, с. 783); носом до носа; ніс у ніс (1, с. 558); під [самим] носом у кого (1, с. 559). Просторовий код невід'ємно позв'язаний також із часовим кодом. Це зумовлюється тим, що окультурювання простору визначається усвідомленням категорії часу. Цікавим є використання просторових прийменників для вираження часових відношень: з дня на день (ФСУМ, с. 226); без року тиждень (ФСУМ, с. 739).

Просторовий культурний код українського етносу в системі мови є антропо-предметно-орієнтованим, пов'язаним 3 аксіологічними опозиціями етносвідомості та 3 іншими кодами культури шляхом уподібнення: до розуму (у розум) приходити, прийти (1, с. 63). Це виявляється, по-перше, у використанні знаків локалізації на позначення 
станів, якостей, дій, вчинків людини, часу тощо; по-друге, - в акумуляції різних концептосфер власними мовними ресурсами на позначення просторової орієнтації. Так, у кодуванні фрагментів буття людини у світі категорії простору й часу є нерозривними.

Часовий код культури - це уявлення людини про матеріальні й нематеріальні світи через часову вісь. Часовий код культури фіксує членування часової осі, відображає рух людини за нею, кодує буття людини в матеріальному й нематеріальному світі та виявляється у ставленні людини до часу. Те, що знаходиться позаду, стосується минулого, а те, що в усталених сполуках фіксується, як на носі, належить майбутньому: з року до року (ФСУМ, с. 617), не за наших часів; не за нас; не за намої пам'яті; на вічні часи; (1, с. 150) .

Мовна система містить одиниці з темпоральним компонентом на позначення дій, які виконуються над часом: витрачати, програвати, вигравати, губити, знаходити, тягнути, підганяти, не поважати, не зважати на час, вбивати (1, с. 151-152). У репрезентантах часового коду відбито темпоральні уявлення й давнє осмислення неопосередкованого зв’язку простору і часу. Усталені словесні комплекси, які відбивають часовий код, відображають рух суспільства за віссю часу. I час, і простір тісно пов'язані в національній свідомості, що знайшло реалізацію в мовній системі: знай своє місие $і$ час $(1$, с. 150).

Найчисленнішими $€$ репрезентанти предметного коду етнокультури. Під предметним кодом культури розуміють уявлення людини про дійсність через відношення до предметів. Так, у мовній свідомості крапля, краплинка - один 3 еталонів метричної сфери, невелика кількість будь-чого, співвідносного з речовиною або речовими субстанціями: вода, море, озеро, океан - дощ, злива, роса, як-от: крапля 8 морі (СФУМ, с. 311); ложка дьогтю зіпсує бочку меду (СФУМ, с. 353). Концепти кров, вино асоціюються з такими вимірювальними одиницями, як невелика частина, трохи (трішки): крапля крові - або, навпаки, багато: хильнути склянку вина (1, с. 104).

Предметний код культури належить у першу чергу до концепту реальність загальної етнічної концептосфери, пов'язаний із предметами, спрямованими на заповнення простору та належить до реалій навколишнього світу. Він тісно пов'язаний із духовним кодом крізь соціальні стосунки й відношення: наприклад, концепти «дім», «xama» означають уявлення про господарство, тобто про майно або багатство: Своя господа (домівка, хата); свій дім; Хата господарем стоїть; у домі (у господі) - аж через віния ллється; дім його - повна чаша $(1$, с. 277$)$. Окрім того, поняття дому має принципове значення ๑) Н. М. Шарманова, 2013. 
для такої опозиції, як «свій - чужсии». Дім - це місце, де локалізуються «свої». Двір - частина у сього великого дому. Маючи огорожу, він захищає дім від нечистих сил. Але разом із тим дім межує із зовнішнім, «чужим» світом, становить простір, у якому може зникати межа між «своїм» і «чужим» світами, що $є$ потенційно небезпечним для жителів дому, як зазначає В. В. Красних [3, с. 245].

Предметний код може накладатися на інші культурні коди, наприклад соматичний: кісткою в горлі стати (ФСУМ, с. 377); кістка поперек горла стала (ФСУМ, с. 378); часовий: за спиною досвід минулих років (ФСУМ, с. 847), за плечима вивченого не носити (ФСУМ, с. 691); духовний код: брати, взяти на свою душу (на себе) (1, с. 62); колесо фортуни, щзастя (долі); коловорот долі (1, с. 406); Сумнів (непевність, вагання зневір'я) бере його (1, с. 63); антропологічний: запрягати, запрягти в ярмо кого; накидати, накинути ярмо на кого; підгортати, підгорнути (підбивати, підбити) під кормигу кого (1, с. 863); скинути з себе ярмо (кормигу) $(1$, с. 863) і т. ін.

Відтак предметний код указує на конкретність національного світогляду, що виражається в різних уявленнях людини про будь-який предмет, співвідносний із речовими субстанціями.

Зв'язок біоморфного культурного коду яскраво розкривається крізь призму етнічних стереотипів. Біоморфним кодом культури позначають уявлення людини про світ стосовно взаємовідносин 3 істотами, усім живим. Він пов'язаний із життєздатними істотами, якими наповнена реальність. Крім того, тут чітко відстежується стереотипізація, і перш за все етнічна.

Етнічними стереотипами номінують відносно стійкі, схематизовані уявлення, судження, емоційно забарвлені оцінки моральних, розумових, фізичних тощо якостей, характерних для представників різних етнічних спільнот [1, с. 165]. Так, в українському семіозисі є низка усталених словесних комплексів 3 лексемою віл, яка відбиває стандартний етнічний портрет працьовитих українців. Наприклад: як (чорний /той/) віл [зі словами робити, праџювати] - дуже важко, надмірно (ФСУМ, с. 129); як віл [зі словом здоровий] уживається для підсилення ознаки (10, с. 129). Зі сміховою культурою українців співвідноситься усталений комплекс Чорний віл на ногу наступив - хто-небудь одружився і зазнав усіх неприємностей, пов' язаних із подружнім життям (ФСУМ, с. 129). Зневажливу семантику подає ряд мовних одиниць на кшталт як віл до браги [зі словами допастися, добратися] - без почуття міри, жадібно (ФСУМ, с. 129); як віл на рогатину [зі словами лізти, йти] - настирливо, вперто, нехтуючи 
небезпекою (ФСУМ, с. 129); як віл обуха / перед обухом/ використовується з фатальною невірою в можливість відвернення якоїсь загрози, небезпеки; покірно, приречено, безнадійно (ФСУМ, с. 129).

Абстрагуючись від біологічної класифікації тварин, серед усталених словесних комплексів виокремлюємо такі одиниці, стрижневим компонентом яких є: 1) свійські тварини - вівия: приблудна вівия (ФСУМ, с. 113); дурна вівия (ФСУМ, с. 111); собака: битий собака (ФСУМ, с. 838); дивився собачими очима (ФСУМ, с. 465); кінь: троянський кінь (ФСУМ, с. 377); коні й князі терпіти не вміють (ФСУМ, с. 443); осел: Валаамова осличя (ФСУМ, с. 591); осляча впертість (ФСУМ, с. 552). У слов'янських культурах, наприклад, образ віслюка асоціюється 3 когніціями «тупий» («упертий»). По-іншому сприймають його американці: осел у них це уособлення чиновника, урядовця. На Сході й у Середній Азії цей концепт має майже протилежне маркування - це символ трударя - та визначається як унікалія, що пояснюється багатьма антропо-, етно-, історико-, соціо- та іншими чинниками; 2) дикі звірі - ведмідb: ведмідь на вухо наступив (ФСУМ, с. 72); з ведмедями барложився (ФСУМ, с. 73); вовк: вовк у овечій шкурі (ФСУМ, с. 139); мав на спині вовчу шкуру (ФСУМ, с. 470); 3) птахи - гусак: як з гусака вода (ФСУМ, с. 203); мов гусак од води (ФСУМ, с. 203); сова: як сова (ФСУМ, с. 841); сова про сову, а всяк про себе (ФСУМ, с. 842); сич: ні сич, ні сова (ФСУМ, с. 807); мов сич (ФСУМ, с. 802) тощо; 4) плазуни: гадюка ссе коло серия (ФСУМ, с. 167); як гадюка стару шкіру (ФСУМ, с. 169); 5) риби: ні риба, ні м'ясо (ФСУМ, с. 735); мов з риби ікру (ФСУМ, с. 736). Загалом зооморфний світ, відбитий в українській мовній системі, дав багату систему національних еталонів: осел впертий; вівця - покірна й дурна; гадюка - підла; вовк - хижий; ведмідь - незграбний і сильний; собака - вірна; риба - мовчазна тощо.

Світ рослин представлений в усталених сполуках меншою мірою. Важливим етнокодом $є$ зернові культури, що репрезентовано усталеними сполуками на зразок на припічку жито (пшенищю) сіяти [й молотити] (1, с. 763); Сій овес у кожусі, жито - в брилі (1, с. 586). Квіти у давні часи мали ритуальну специфіку, що знайшло відображення в обрядах, особливо в родинних. Із світу квітів найбільше стереотипізується еталон мак: на макове зерня (ФСУМ, с. 461); маків иявіт, як макове зернятко (ФСУМ, с. 463).

Біоморфний код культури відтворює уявлення людини про світ бестії, який знаходиться в прикордонній ментальній зоні, перетинаючись iз двома розглянутими вище біоморфними площинами - світом 
тварин і цариною флори. Бестії належать до «вторинної реальності» народного фольклору та входять до дійсності, виступаючи невід'ємними елементами культурного простору. Подібно до представників флори й фауни, бестії не тільки існують в культурі як образи або елементи фольклору. Їм притаманні стереотипи, що робить можливими апелювання до їхніх образів у розмовному дискурсі: великому чорту - велика яма (ФСУМ, с. 954). Проте щодо вживання подібних сполук слід зауважити, що вони належать до табу в українській (і не тільки) свідомості.

Отже, біоморфний код культури - це світосприйняття людини за допомогою виокремлення, зіставлення певних ознак, якостей живих істот з якостями людини, що часто використовується в мовних одиницях, відображаючи риси національної культури, свідомості.

Розуміння антропологічного (антропного, антропоморфного) коду культури грунтується на відомостях з антропології, що дозволяє створити загальну, панорамну картину світу, уточнити характерні особливості самої людини. Антропологічний код розглядається як спосіб сприйняття й оцінки світу відповідно до національнокультурної специфіки, його становлять моральні якості, які зумовлюють людську поведінку.

За народним переконанням, найцінніший скарб людини - iii розум: мати добрий розум; бути при здоровому (при повному) розумі; бути сповна розуму; жити своїм розумом; покладатися на свій розум $(1$, c. 832). Розум - показник того, як людина працювала над собою, вік не можна вважати критерієм оцінювання інтелектуального розвитку: розумний не на свої літа $(1$, с. 833$)$. Розум протиставляється багатству: Розуму $i$ за гроші не купиш; Не купити ума, як нема (1, с. 833). В опозиції - відсутність розуму, інтелекту: з дурнів дурень; удавати (грати) дурня (дурного); прикидатися дурнем (дурним); 3 дурного розуму (ума); з дурної голови (1, с. 202); розумом не дійшли; глузд за розум завертає (заходить); з великого розуму у дур заходить (1, с. 833). Виразно це представлено в одиницях, які актуалізують концепти-репрезентанти інших кодів: ума ні з шило нема; розуму ані ложки; розуму в голові ні на макове зерня (ні на мачину); дурний - далі нікуди (1, с. 202). Антропологічний код є специфічним національнокультурним способом сприйняття й оцінки світу, він відображає ті моральні й духовні якості людини, необхідні для гідного життя.

Аксіологічність духовного коду культури відображає культурні універсалії, хоч і має виразне етнічне маркування. До духовного коду культури зараховують вербальні уявлення людини про реальний світ 
через духовність. Його складають моральні цінності, еталони, ідеали та пов'язані з ним базові опозиції культури. Духовна царина розкривається в системі української мови репрезентацією сакральної сфери, духовної культури й основних моральних категорій: добро - зло: зганяти зло (ФСУМ, с. 339); не перед добром (ФСУМ, с. 253); добре - погане: добре слово замовити (ФСУМ, с. 253); до щуастя й добра шлях завжди предовгий, а до лиха - раз ступнути (ФСУМ, с. 140) тощо.

Саме духовний код акумулює цінності українців, які становлять основу його світоглядної оцінки - позитивної чи негативної, що знаходить відображення на рівні щоденного вжитку стереотипних мовних одиниць. Так, у безпосередніх побутових ситуаціях різноманітні ритуальні словесні комплекси на позначення привітання, побажання, прощання, прохання, вибачення, застереження, подяки із концептом Бог: Дай Боже здоров'я; Поздоров Боже; Щасти Боже; Коли (як) воля Божа; Дійся воля Божа; (1, с. 48); Поздоров, Боже (1, с. 348); Дай Боже!; (1, с. 48); Бога ради; на бога; на бога зглянься; (1, с. 49); Бачить Бог; Бог все бачить; Бог знає (Бог відь, Бог віда); Бог те знає, а не ми; Бог розсудить; ій-бо[гу]; їй же Богу! присягай-бо[гу]; присягай-біг (1, с. 48); Не дай Боже; крий (боронь, борони, ховай) Боже; Хай Бог (Господь) милує; [не]хай Бог боронить (ховає); не доведи Господи (1, с. 49); Прости, Господи (1, с. 732) Слава Богу; хвалити Бога (1, с. 49).

Отже, коди культури становлять систему координат, яка містить в собі еталони етнічної культури. Розглянуті базові культурні коди: соматичний, просторовий, часовий, предметний, біоморфний, антропологічний і духовний - визначають етноментальну, моральноеталонну сферу, що бере участь у структуруванні й оцінюванні навколишнього світу. В усталених словесних комплексах відбито весь спектр лінгвокультурних кодів. Саме вони утворюють національну концептосферу, яка утримує етнічні уподобання й еталони поведінки, що дозволяє говорити про відображення базових кодів в українській мовній системі загалом.

\section{Література}

1. Бацевич Ф. С. Словник термінів міжкультурної комунікації / Ф. С. Бацевич. К. : Довіра, 2007. - 205 с.

2. Ковшова М. Л. «Культурный код» как элемент культурной интерпретации фразеологизмов в лингвокультурологической парадигме исследования / М. Л. Ковшова // Знание. Язык. Культура : Материалы Междунар. научной конференции. - Тула : Петровская Гора, 2007. - С. 30-33.

3. Красных В. В. Этнопсихолингвистика и лингвокультурология : [курс лекций] / В. В. Красных. - М. : ИТДГК «Гнозис», 2002. -284 с.

4. Савченко Л. В. Феномен етнокодів духовної культури у фразеології української 
мови : етимологічний та етнолінгвістичний аспекти : [монографія] / Л. В. Савченко. Сімферополь : Доля, 2013. - 600 с.

5. Станкевіч А. А. Раслінны код вясельнай абраднасці : назвы вясельнага дрэўца ў гаворках Веткаўскага і Добрушскага раёнаў Гомельшчыны / А. А. Станкевіч // Славянская фразеология в синхронии и диахронии : сб. науч. статей. - Вып. 1 / редкол. В. И. Коваль (отв. ред.) [и др.]. - Гомель : ГГУ им. Ф. Скорины, 2011. - С. 148-150.

6. Телия В. Н. Первоочередные задачи и методологические проблемы исследования фразеологического состава языка в контексте культуры // Фразеология в контексте культуры / отв. ред. В. Н. Телия. - М. : Языки рус. культуры, 1999. - С. 13-24.

7. Толстая С. М. Слово в контексте культуры / С. М. Толстая // Пространство слова. Лексическая семантика в общеславянской перспективе. - М. : Индрик, 2008. - 527 с.

\section{Список використаних джерел}

1. Вирган I. О. Російсько-український словник сталих виразів / I. О. Вирган, М. М. Пилинська ; за ред. М. Ф. Наконечного. - Х. : Прапор, 2009. - 864 с.

2. ФСУМ - Фразеологічний словник української мови / за ред. В. М. Білоноженко : у 2-х т. - К. : Наукова думка, 1993. - 984 с.

3. СФУМ - Словник фразеологізмів української мови / за ред. В. М. Білоноженко. К. : Наукова думка, 2003. - 1104 с.

Стаття надійшла до редакції 21.11.2013 р. 